\title{
Diagnoses and nursing interventions in hypertensive and diabetic individuals according to Orem's Theory
}

\author{
Diagnósticos e intervenções de enfermagem em indivíduos hipertensos e diabéticos à luz de \\ Orem
Diagnósticos e intervenciones de enfermería en individuos hipertensos y diabéticos a la luz de Orem

Priscila Camara de Moura ${ }^{1}$, Luciene Muniz Braga ${ }^{2}$, Camila Santana Domingos ${ }^{1}$, Nayara Vilela Rodrigues ${ }^{2}$, Marisa Dibbern Lopes Correia², Laís Vanessa Assunção Oliveira²

This study aimed to identify the most prevalent nursing diagnoses in hypertensive and diabetic patients in the Family Health Care Unit, according to Orem's conceptual model. A descriptive study was conducted from April to November 2013, using a nursing assessment based on Orem's theory and NANDA-I taxonomy. 16 nursing diagnoses were identified on Universal self-care requisites, nine on Health deviation requisites and two on Developmental self-care requisites, the most prevalent being: "Risk for unstable blood glucose level" (60\%), "Ineffective self-care management" (50\%) and "Disposition for improved knowledge" (36.6\%). Teaching (83.3\%) and support/instruction (100\%) actions were implemented in nursing care planning. It can be concluded that there is a need to implement nursing activities directed to offering education on Family Health practices.

Descriptors: Nursing Theory; Hypertension; Diabetes Mellitus; Nursing Diagnosis.

Objetivou-se identificar os Diagnósticos de Enfermagem mais prevalentes em indivíduos hipertensos e/ou diabéticos de uma Unidade de Saúde da Família Mineira, Brasil, segundo o modelo de Orem. Realizou-se investigação descritiva, de abril a novembro de 2013, utilizando histórico de enfermagem, fundamentado na teoria de Orem e taxonomia da NANDA-I. Foram identificados 16 diagnósticos de enfermagem nos requisitos universais, nove nos desvios de saúde e dois nos desenvolvimentais, sendo os mais prevalentes: "risco de glicemia instável" (60\%), "autocontrole ineficaz da saúde" (50\%) e "disposição para conhecimento melhorado" (36,6\%). No planejamento da assistência de enfermagem foram implementadas ações de ensino (83,3\%) e apoio/educação (100\%). Concluímos necessidade de implementação de ações de enfermagem direcionadas à educação em saúde no âmbito da Saúde da Família.

Descritores: Teoria de Enfermagem; Hipertensão; Diabetes Mellitus; Diagnóstico de Enfermagem.

El objetivo fue identificar los Diagnósticos de Enfermería más frecuentes en hipertensos y/o diabéticos de una Unidad de Salud Familiar de Minas Gerais, Brasil, según el modelo conceptual de Orem. Investigación descriptiva, llevada a cabo de abril a noviembre de 2013, utilizándose registro de enfermería, basado en la teoría de Orem y taxonomía NANDA-I. Se identificaron 16 diagnósticos de enfermería en los requisitos universales, nueve en los desvíos de salud y dos en los de desarrollo, los más frecuentes fueron: "riesgo de glicemia inestable" (60\%), "autocontrol ineficaz de salud" (50\%), y "disposición para conocimiento mejorado" (36,6\%). En el plan de la atención de enfermería, fueron implementadas acciones de enseñanza $(83,3 \%)$ y apoyo/educación (100\%). En conclusión, hay necesidad de acciones de enfermería direccionadas a la educación en salud en el contexto de la Salud Familiar.

Descriptores: Teoría de Enfermería; Hipertensión; Diabetes Mellitus; Diagnóstico de Enfermería.

\footnotetext{
${ }^{1}$ Universidade Federal de Juiz de Fora. Juiz de Fora, MG, Brazil.

${ }^{2}$ Universidade Federal de Viçosa. Viçosa, MG, Brazil. 


\section{Introduction}

"Hypertension is a multifactorial clinical condition characterized by high and sustained levels of blood pressure"(1:7). Many factors are related to the occurrence of systemic hypertension, being age, gender, ethnicity, overweight, obesity, salt intake, alcohol intake, and socioeconomic and genetic factors. Some of these are modifiable or preventable, and therefore it is essential for nursing performance to act on the prevention and health promotion ${ }^{(1)}$ for this population group affected by such morbidity in the Family Health Strategy units.

Brazilian research in 2013 identified 31.3 million of people older than 18 years diagnosed with hypertension (21.4\%), the Southeast Region havingpresented the highest proportion (23.3\%), followed by the Northeast $(19.4 \%)$ and North $(14.5 \%)^{(2)}$.

Diabetes Mellitus also affects individuals with hypertension and it requires the attention of nurses of the Family Health Strategy. For Diabetes Mellitus type 1 and 2, the professional should suspect diabetes with an age higher than or equal to 45 years old, consider their family history, obesity, hypertension and dyslipidemia as some of the risk factors that may be associated with signs/symptoms such as polyuria, nocturia, polydipsia, dry mouth, polyphagia, and weakness ${ }^{(3)}$.

In 2013, National Health Research in Brazil showed that $6.2 \%$ of the population over 18 years or older reported a medical diagnosis of diabetes, the equivalent of 9.1 million people. The North (4.3\%) and Northeast (5.4\%) regions were the ones that had the lowest proportions of this indicator. Considering the household situation in the urban area, people aged 18 or older reported having a medical diagnosis of diabetes $(6.5 \%)$, while in rural areas the proportion was lower $(4.6 \%)^{(2)}$. Data from the Primary Care Information System ${ }^{(4)}$ showed that until the month of June 2014, 1,151 diabetic patients have been registered in the Basic Health Units of Viçosa-MG $\mathrm{M}^{(4)}$. A previous study in this location identified that among 2,951 patients seen in a Family Health Unit, 324 were treated for hypertension $(10.9 \%)$ and 84 for diabetes mellitus $(2.8 \%)$. Despite being smaller proportions to the national average, knowing the nursing problems of these individuals is essential to the planning of nursing and health, in view to identifying complications and implementing care for health prevention and promotion.

The development of nursing care in many practice scenarios guided by a care model is essential. Nursing theory is the basis for implementing the systematization of nursing care through the steps of the nursing process that "must be performed deliberately and consistently in all environments, public or private, in which professional nursing care occurs"(5-2).

In patients with chronic medical condition, Dorothea E. Orem's Self-Care Deficit Theory of nursing is considered an option for the structuring of nursing practice and direction of assistance actions to respond to patient needs. The theory reflects self-care when the actions are done by individuals and for their own benefit ${ }^{(6)}$, requiring that the patient is willing to self-care and have understanding in relation to their clinical condition.

Orem elaborates three theoretical assumptions: "Theory of Self-Care," "Self-Care Deficit Theory" and "Theory of Nursing Systems" which together aim to care for the individual. The first relates to the individual's need for self-care actions, with an ongoing practice to maintain life and health and recovery from illness. The second deals with the offer of nursing care if the individual cannot perform their self-care alone. Finally, the last assumption is based on the needs of self-care and in the individual capabilities to perform self-care activities ${ }^{(6)}$.

Orem also works with the four fundamental concepts of nursing theory: human beings, health, society and nursing. As for humans, the theorist highlights that it is a thinking being capable of learning and development. Therefore, this interferes with the 
ability of individual self-care because during the development of life you learn how to take care of yourself. She points out the various factors that interfere with learning such as age, mental capacity, culture, society and the emotional state of the individual. This role of nursing care for people with quality of service, being that the nurse's role is complemented by the patient as it works with them to achieve self-care ${ }^{(6)}$.

The nursing process is divided into three steps which involve: diagnosis and prescription (data collection and identification of care needs); planning of nursing systems and planning the execution of nursing actions (fully compensatory system, partially compensatory or support-education); evolution (stage in which nurse and patient perform the evaluation process). Through the nursing process proposed by Orem, it is possible to identify self-care deficits and define the individual or nursing tasks to consider the self-care requirements ${ }^{(7)}$.

Considering that chronic diseases are responsible for $72 \%$ of all deaths in the Brazilian states and cardiovascular diseases represent $31.3 \%$ of this mortality ${ }^{(8)}$; that the methodology of the systematization of nursing care provides comprehensive care and is able to detect health problems that require nursing interventions and direct care to achieve the well-being( ${ }^{(9)}$ and the role of nurses in the Family Health Strategy units, the following research question arose: What are the nursing diagnoses in hypertensive and/or diabetic patients of a Family Health Unit in a rainforest zone of Minas Gerais, according to the conceptual model of Orem?

To address this issue, we developed research in order to identify nursing diagnoses in hypertensive and/or diabetic individuals of a Family Health Unit in a rainforest zone of Minas Gerais, according to the conceptual model of Orem.

\section{Methods}

A descriptive study, developed in a Family Health Unit in a rainforest zone of Minas Gerais. Data collection was carried out from April to November 2013 using convenience sampling and included: 30 people of both genders, above 40 years of age, enrolled in a Family Health Unit, with hypertension and/or Diabetes Mellitus. The choice of this age group is justified because this is the most prevalent in the Family Health Unit in research with these comorbidities, according to results of the situational diagnosis made in 2010 . The exclusion criteria were: women with hypertension and/or gestational diabetes.

To develop the study, home nursing visits were previously scheduled with adjustments as to subject availability. An instrument validated by experts organized according to Orem's Theory of Requirements and the Domains of NANDA-I ${ }^{(10)}$ was used for development of consultations. From the Universal Self-care Requisites, the following were investigated: health promotion, nutrition and hydration, elimination, activity and rest, self-perception, roles and relationships, sexuality, life principles, safety and security, and comfort. For Human Development Requirements, the following were evaluated: current disease history, life changes with hypertension/diabetes, family history. In Health Deviation Requisites, the following were observed: health-disease process, nutrition and hydration, elimination and exchange, activity and rest, perception and cognition, perception, roles and relationships, sexuality, coping/stress tolerance, principles of life, safety and security, comfort and vital signs. After the clinical reasoning deficits patient self-care was identified, followed by the classification of nursing systems (Total Compensation, Partial Compensation, Educative/Supportive).

Data collected from the nursing consultation were analyzed, categorized and grouped using clinical 
reasoning and subsequently diagnostic reasoning ${ }^{(11)}$. In this last step we used the taxonomic system of NANDA-I ${ }^{(10)}$.

During the nursing consultation, guidelines were explained to patients in accordance with the identified nursing problems and these were then discussed with the nursing staff of the Unit after the data analysis, and educational activities for patients were planned with a view to solving the problems, according to the identified nursing care needs.

Each patient could receive more than a nursing diagnosis and these were grouped in Requirements, Nursing Systems and also with the help of methods proposed by the Theory of Orem, quantified in absolute and relative frequencies, and discussed according to the theoretical framework on the subject.

The research complied with the legal and ethical recommendations for research involving human subjects with a favorable opinion granted from the Ethics Committee of the Federal University of Viçosa (Protocol 236.679/2013).

\section{Results}

30 nursing visits to 19 women (63.3\%) and 11 men (36.7\%) were performed. Most individuals were aged between $60-84$ years $(80 \%)$ and had completed elementary school (66.6\%). Of the respondents, $53.3 \%$ had both diseases (had systemic hypertension and diabetes mellitus) $36.6 \%$ had systemic hypertension and other (10\%) Diabetes Mellitus. The titles of nursing diagnoses were grouped according to Orem's theory on Universal self-care requisites, Developmental self-care requisites and Health deviation requisites, are presented in Table 1.
Table 1 - Titles of the most prevalent nursing diagnoses in hypertensive and/or diabetic according to the taxonomy of NANDA-I and Orem's Theory of requirements. $\mathrm{n}=30$

\begin{tabular}{|c|c|}
\hline Titles of Nursing Diagnoses & n (\%)* \\
\hline \multicolumn{2}{|l|}{ Universal self-care requisites } \\
\hline Risk for unstable blood glucose level & $18(60,0)$ \\
\hline Ineffective self-care & $15(50,0)$ \\
\hline Readiness for enhanced knowledge & $11(36,6)$ \\
\hline Sedentary lifestyle & $9(30,0)$ \\
\hline Readiness for enhanced health management & $8(26,6)$ \\
\hline Readiness for enhanced self-care & $5(16,6)$ \\
\hline Ineffective family health management & $4(13,3)$ \\
\hline Risk-prone health behavior & $3(10,0)$ \\
\hline Bathing self-care deficit & $3(10,0)$ \\
\hline Dressing self-care deficit & $3(10,0)$ \\
\hline Ineffective health maintenance & $2(6,6)$ \\
\hline Imbalanced nutrition: less than body requirements & $2(6,6)$ \\
\hline Constipation & $1(3,3)$ \\
\hline Sexual dysfunction & $1(3,3)$ \\
\hline Impaired skin integrity & $1(3,3)$ \\
\hline Self-neglect & $1(3,3)$ \\
\hline \multicolumn{2}{|l|}{ Health deviation requisites } \\
\hline Risk of falls & $10(33,3)$ \\
\hline Impaired physical mobility & $5(16,6)$ \\
\hline Stress overload & $5(16,6)$ \\
\hline Risk for impaired oral mucous membrane & $5(16,6)$ \\
\hline Impaired knowledge & $2(6,6)$ \\
\hline Chronic pain & $2(6,6)$ \\
\hline Impaired teething & $2(6,6)$ \\
\hline Interrupted family processes & $1(3,3)$ \\
\hline Acute pain & $1(3,3)$ \\
\hline \multicolumn{2}{|l|}{ Developmental self-care requisites } \\
\hline Hopelessness & $1(3,3)$ \\
\hline Social Isolation & $1(3,3)$ \\
\hline
\end{tabular}


Table 2 - Distribution of hypertensive and/or diabetic individuals according to Orem's healthcare method and nursing systems. $\mathrm{n}=30$

\begin{tabular}{lc}
\hline Healthcare methods/Nursing systems & $\mathbf{n}(\%)$ \\
\hline Healthcare Methods & $25(83,3)$ \\
Teaching & $9(30,0)$ \\
Guiding & $3(10,0)$ \\
Act toward others & $3(10,0)$ \\
Physical or emotional support & - \\
Promotion of an environment for personal \\
development & \\
Nursing Systems & \\
Supportive-Educative & $30(100)$ \\
Partially Compensatory & $3(10,0)$ \\
Wholly Compensatory & - \\
\hline
\end{tabular}

Most self-care needs were related to education (83.3\%), which was confirmed when $100 \%$ of participants interviewed were classified in the Educative-Supportive nursing system.

\section{Discussion}

One of the biggest challenges for the control of diabetes mellitus in order to minimize its complications is to keep blood glucose levels within the normal parameters ${ }^{(12)}$. This research confirms this statement when it identified the title of the nursing diagnosis "unstable blood glucose risk" as the most prevalent. The main risk factor was food intake, with the Basic Care nurse being sensitive to this issue and intervene by instigating nutritional guidelines for restricting calories or reducing carbohydrates ${ }^{(5)}$. In addition to direct nursing care, other actions to control diabetes associated with the change in lifestyle are also necessary as part of care developed by the patient; the re-education of eating habits, which mainly depends on the patient's membership and their families ${ }^{(12)}$.

For this prospect of adhering to the health recommendations, the title of "ineffective self-health" was related to choices in daily life which ineffective to achieve the health goals of the nursing diagnosis. Most respondents had difficulties to act in favor of the health goals proposed by the treatment, often restrictive, prescriptive and prohibitive ${ }^{(12)}$, which can result in non-compliance and the wrong choices. The strict control of blood pressure and blood glucose can reduce the systemic hypertension and diabetes mellitus ${ }^{(12)}$ complications. Thus, an important point was identified in that $36.6 \%$ of the investigated individuals had the title diagnosis of "readiness for enhanced knowledge," which can facilitate health education strategies for disease control and disease prevention.

The successful control of blood sugar and blood pressure is subject to the adherence of an individual to treatment and health activities that encourage or facilitate changes in lifestyle ${ }^{(12)}$. Thus, the occurrence of $26.6 \%$ of the nursing diagnosis title of "readiness for enhanced health management" confirms the need for nurses of the Family Health Strategy to implement activities that encourage and enhance compliance.

The educational activities developed by the extension project above are essential, given that the majority of self-care deficits were related to education, but in addition, it is necessary that the staff of the Family Health Strategy become proactive in these activities. In this sense, nurses should consider the low level of education of the sample, in which $66.6 \%$ of subjects had only finished elementary school. So to deal with this situation, a health education model needs to be based on empowerment, and the development of participatory learning in principle, considering the needs of individuals ${ }^{(13)}$.

Orem highlights the role of nursing in relation to encouraging the patient to be proactive in their self-care ${ }^{(6)}$. The way the information from nurses and other health professionals are transmitted can provide greater performance of the individual for the sake of their health. For this to happen, it is necessary that the client-nurse therapeutic relationship is established and that both participate in the care process, thus setting up a support and education system ${ }^{(14)}$. 
This system aims to prevent complications associated with systemic hypertension (heart disease, stroke and kidney complications) ${ }^{(1)}$ and Diabetes Mellitus (heart disease, blindness, kidney disease and amputation of extremities) $^{(15)}$ and achieve well-being in the person.

Most nursing diagnoses were classified into Universal self-care requisites, which was also observed in other studies ${ }^{(15-16)}$. These requirements which cover life processes of operating and maintenance stages of the body ${ }^{(6)}$ are related to the control of systemic hypertension and diabetes mellitus, thus explaining the fact of obtaining a larger number of nursing diagnoses in this requirement.

The title of the nursing diagnosis "sedentary lifestyle" is very important to control these chronic diseases, as well as for the maintenance of health. Physical inactivity is considered by the World Health Organization as a risk factor for chronic diseases and the main public health problem, and is responsible for the majority of health problems, according to the World Bank $^{(17) .}$

In this regard, regular physical activity acts as treatment and prevention of diseases and disorders such as Diabetes Mellitus and Hypertension ${ }^{(17)}$. For these benefits to occur, the World Health Organization recommends at least 150 minutes of aerobic physical activity of moderate intensity or at least 75 minutes of aerobic activity with vigorous intensity throughout the week ${ }^{(18)}$ for adults over 65 . In this sense, awareness and encouraging physical activity is necessary, in addition to activity programs with a physical educator in the Family Health Strategy unit in order to change this situation, to provide disease control and improve health and quality of life.

In the Health Disorders Requirement, the title of the most frequent nursing diagnosis was the "risk of falling," which is mainly associated with age over 65 years of the majority of the sample, and the reactions of antihypertensive drugs that may lead the individual to fall from a height because of hypotension ${ }^{(19)}$. Thus, it is important that the nurse instructs patient care in order to prevent falls, as in not performing any sudden movements to get up; to use auxiliary devices such as a cane or walker; and identify the risk factors in the home, such as furniture and excess objects, rugs on the floor, no non-slip tread on the bathroom floor, etc $^{(20)}$.

\section{Conclusion}

The most prevalent nursing diagnoses in hypertensive and $\backslash$ or diabetic subjects were "risk for unstable blood glucose level," "ineffective self-care" and "readiness to enhance knowledge." The research results allowed for planning educational activities which are being implemented during the extension project activities and by the Unit's nurses.

Orem's theoretical support has enabled implementation of nursing consultations and supported the implementation of other phases of the nursing process: nursing diagnosis, planning and implementation.

The results of this study are relevant to nursing since they contribute to the consolidation of the Systematization of Nursing Care and Nursing Process. Thus, nurses act in the prevention of disease and injury and in promoting health with their role of orientation and the patient becomes proactive in self-care. The study benefited patients with quality nursing care aiming at a comprehensive consultation, listing the nursing diagnoses and after their interventions, contributing to a better quality of life.

Limitations to the study include: the sample size and sampling for convenience and the lack of evaluation of results according to nursing interventions. The limitations are related to the short follow-up of subjects because of the need to stop the data collection as the researchers were completing their course degrees. So research with a larger sample using Orem's theory and implementing all phases of the nursing process to support the discussion and scientific basis for the work of nurses is suggested with a view towards disease prevention and health promotion. 


\section{Acknowledgements}

To the Family Health Care Unit of Silvestre in Viçosa, Minas Gerais, the Institutional Scholarship Program for Continuing Education of the Federal University of Viçosa and the Higher Education Personnel Training Coordination for funding, process 0867/14-4.

\section{Collaborations}

Moura PC, Domingos CS and Rodrigues NV contributed to the literature review, data collection, interpretation, data analysis and writing of the article. Braga LM and Correia MDL contributed to the literature review, interpretation, data analysis and writing of the article. Oliveira LVA contributed to data collection.

\section{References}

1. Sociedade Brasileira de Cardiologia. Sociedade Brasileira de Hipertensão. Sociedade Brasileira de Nefrologia. VI Diretrizes Brasileiras de Hipertensão. Arq Bras Cardiol. 2010; 95(1Suppl 1):I-III.

2. Ministério da Saúde (BR). Pesquisa Nacional de Saúde 2013: Percepção do estado de saúde, estilos de vida e doenças crônicas. Brasil, Grandes Regiões e Unidades da Federação. Rio de Janeiro: Ministério da Saúde; 2014.

3. Ministério da Saúde (BR). Secretaria de Atenção à Saúde. Departamento de Atenção Básica. Estratégias para o cuidado da pessoa com doença crônica: diabetes mellitus. Brasília: Ministério da Saúde; 2013.

4. Ministério da Saúde (BR). Sistema de Informação da Atenção Básica. [Internet]. 2014 [citado 2014 13 jun]. Disponível em: http://tabnet.datasus.gov. br/cgi/tabcgi.exe?siab/cnv/SIABSMG.def
5. Ministério da Saúde (BR). Conselho Federal de Enfermagem. Resolução no 358, de 15 de Outubro de 2009. Dispõe sobre a Sistematização da Assistência de Enfermagem e a implementação do Processo de Enfermagem em ambientes, públicos ou privados, em que ocorre o cuidado profissional de Enfermagem, e dá outras providências. Brasília: Ministério da Saúde; 2009.

6. Hartweg DL, Fleck LM. Chapter 9 Dorothea Orem's Self-Care Deficit Theory In: Parker ME, Smith MC. Nursing theories and nursing practice. Pennsylvania: F. A. Davis Company; 2010. p.121-45.

7. Herculano MMS, Sousa VEC, Galvão MTG, Caetano JA, Damasceno AKC. Aplicação do processo de enfermagem a paciente com hipertensão gestacional fundamentada em Orem. Rev Rene. 2011; 12(2):401-8.

8. Ministério da Saúde (BR). Secretaria de Vigilância em Saúde. Vigitel Brasil 2011: vigilância de fatores de risco e proteção para doenças crônicas por inquérito telefônico. Brasília: Ministério da Saúde; 2012.

9. Ferrari RFR, Ribeiro DMM, Vidigal FC, Marcon SS, Baldissera VDA, Carreira L. Reasons that led hypertensive elderly to seek assistance in primary care. Rev Rene. 2014; 15(4):691-700.

10. Herdman TH, organizadora. Diagnósticos de enfermagem da NANDA: definições e classificação 2012-2014. Porto Alegre: Artmed; 2013.

11. Cerullo JASB, Cruz DALM. Clinical reasoning and critical thinking. Rev Latino-Am Enfermagem. 2010; 18(1):124-9.

12. Pontieri FM, Bachion MM. Crenças de pacientes diabéticos acerca da terapia nutricional e sua influência na adesão ao tratamento. Ciênc Saúde Coletiva. 2010; 15(1):151-60.

13. David GF, Torres HC. Health professionals' perceptions regarding interdisciplinary work in educational strategies in diabetes. Rev Rene. 2013;14(6):1185-92. 
14. Lopes MCL, Carreira L, Marcon SS, Souza AC, Waidman MAP. $O$ autocuidado em indivíduos com hipertensão arterial: um estudo bibliográfico. Rev Eletr Enferm. [periódico na Internet]. 2008 [citado 2014 abr 13];10(1):198-211. Disponível em: http://www.fen.ufg.br/fen_revista/v10/n1/pdf/ v10n1a18.pdf

15. Teixeira CRS, Zanetti ML, Pereira MCA. Nursing diagnoses in people with diabetes mellitus according to Orem's theory of self-care. Acta Paul Enferm. 2009; 22(4):385-91.

16. Manzini FC, Simonetti JP. Nursing consultation applied to hypertensive clients: application of Orem's self-care theory. Rev Latino-Am Enfermagem. 2009; 17(1):113-9.

17. Pozena R, Cunha, NFS. Projeto "Construindo um futuro saudável através da prática da atividade física diária". Saúde Soc. [periódico na Internet]. 2009 [citado 2014 abr 13]; 18(suppl.1):52-6. Disponível em: http://www.scielo.br/pdf/sausoc/ v18s1/09.pdf
18. World Health Organization Global. Recommendations on physical activity for health. [Internet]. 2010 [cited 2014 Apr 13]. Available from: http://whqlibdoc.who.int/publications/2010/9789241599979_eng.pdf?ua=1

19. Reinhardt, F, Ziulkoski AL, Andrighetti LH, Perassolo MS. Acompanhamento farmacoterapêutico em idosos hipertensos residentes em um lar geriátrico, localizado na Região do Vale dos Sinos, Rio Grande do Sul, Brasil. Rev Bras Geriatr Gerontol. 2012;15(1):109-17.

20. Bulechek GM, Butcher HK, Dochterman JM. Classificação das intervenções de enfermagem - NIC. Rio de Janeiro: Elsevier; 2010. 